\title{
Genomic diversity of the genus Stenotrophomonas
}

\author{
L. Hauben, ${ }^{1,2}$ L. Vauterin, ${ }^{1,3}$ E. R. B. Moore, ${ }^{2}$ B. Hoste ${ }^{1}$ and J. Swings ${ }^{1}$
}

Author for correspondence: L. Hauben. Tel: +329 2645102. Fax: + 3292645092.

\footnotetext{
1 Laboratorium voor Microbiologie, Universiteit Gent, Ledeganckstraat 35, B-9000 Ghent, Belgium

2 National Research Centre for Biotechnology (GBF), Mascheroder Weg 1, D-38124 Braunschweig, Germany

3 Applied Maths, Risquonstoutstraat 38, B-8511 Kortrijk, Belgium
}

\begin{abstract}
The clinical and environmental importance of Stenotrophomonas bacteria requires thorough, molecular studies on their epidemiology and taxonomy. In order to obtain a complete genomic profile of this genus, over 100 Stenotrophomonas maltophilia strains from various origins were investigated by AFLP fingerprinting. A subset of these strains was analysed by DNA hybridization and 165 rDNA sequencing. In contrast to their high phenotypic homogeneity, the strains were found to be very heterogeneous genotypically by AFLP fingerprinting. Nevertheless, ten cores of highly similar strains representing ten genomic groups were observed. The same groups could be retrieved by DNA hybridizations and also, partly, by 165 rDNA sequence analysis. The intergroup DNA similarities were too high to create confident species delineations, neither could the genomic groups be characterized by phenotypic features.
\end{abstract}

Keywords: Stenotrophomonas maltophilia, genomic groups, AFLP fingerprinting

\section{INTRODUCTION}

Stenotrophomonas maltophilia (Palleroni \& Bradbury, 1993), formerly named Pseudomonas maltophilia (Hugh, 1981) and Xanthomonas maltophilia (Swings et al., 1983), is a commonly found ubiquitous bacterium. It is increasingly prevalent in hospitals as an opportunistic human pathogen causing nosocomial infections. The numerous recent literature reports, dealing with $S$. maltophilia infections and outbreaks, emphasize the importance of this rapidly emerging clinical pathogen. S. maltophilia is a causal agent of infection and colonization of immunocompromised cancer and HIV patients and transplant recipients (Nagai, 1984; Roilides et al., 1992; Spencer, 1995) and has been reported as a cause of bacteraemia and infections of the respiratory tracts (Fisher et al., 1981) and urinary tracts (Vartivarian et al., 1996), post-operative infections (Fisher et al., 1981), ocular infections (Penland \& Wilhelmus, 1996) and a variety of other disease syndromes (Swings et al., 1993). The low outer membrane permeability and the ability to produce $\beta$ lactamases with broad-spectrum activity are responsible for the high degree of resistance towards most commonly used broad-spectrum antibiotics such as

Abbreviations: AP-PCR arbitrarily primed PCR; ERIC-PCR, enterobacterial repetitive intergenic consensus $P C R$; RAPD, random amplification of polymorphic DNA. penicillins and carbapenems (Mett et al., 1988; LescoBornet \& Bergogne-Berezin, 1997; Norrby, 1995; Sanders \& Sanders, 1992). Retrospective studies have shown that $S$. maltophilia is the second most frequently isolated nosocomial bacterium after Pseudomonas aeruginosa (Zuravleff \& Yu, 1982) and that its impact as a multidrug-resistant pathogen increases significantly (Heath \& Currie, 1995; Suzuki et al., 1995). The growing clinical importance of $S$. maltophilia infections has recently been reviewed by Denton \& Kerr (1998).

In the environment, $S$. maltophilia has been isolated as a growth promoting or symbiotic agent from the rhizosphere of plants and crops including chicory, wheat and crucifers (Debette \& Blondeau, 1980; Juhnke et al., 1987), sugar beet (Lambert et al., 1990), sunflowers (Fages \& Arsac, 1991), maize (Lambert et al., 1987), rice (Iizuka \& Komagata, 1963) and orchids (Wilkinson et al., 1994), as well as from soil (Debette \& Blondeau, 1977; Boonchan et al., 1998). As a freeliving micro-organism, S. maltophilia is isolated from a variety of sources, including water and sediment (Aznar et al., 1992), plant tissue cultures (Leifert \& Waites, 1992), sewage, frozen fruit, milk, fermenters (this study), and some unusual habitats such as corroded metal surfaces (Wallace et al., 1994), $\mathrm{NaN}_{3}$ decontaminated Sephadex columns (Borowicz et al., 1995) and oil brine (Iizuka \& Komagata, 1964).

The remarkable diversity of sources from which $S$. 
maltophilia strains have been isolated indicates that these bacteria possess a great variety of enzymic functions necessary for adaptation to different habitats. Many special metabolic and enzymic activities have been described for strains of $S$. maltophilia (Iizuka \& Komagata, 1963). Both the ecological and metabolic diversity of $S$. maltophilia suggests that this species could be taxonomically heterogeneous. Most of the taxonomic literature about $S$. maltophilia deals with the position of this species within or outside the genus Xanthomonas, but little data are available on the genomic relationships among strains of this diverse taxon. Molecular typing studies of S. maltophilia have been conducted recently, but these deal only with strains from clinical origin. Laing et al. (1995) compared 80 strains isolated from three hospitals by PFGE, and concluded that all but six strains had unique genotypes, regardless of the presence or absence of an epidemiological association. These results suggested that most infections were independently acquired, rather than from resident hospital clones. Similarly, Chatelut et al. (1995) found that among 38 S. maltophilia strains, all strains from different patients were different in arbitrarily primed (AP) PCR and enterobacterial repetitive intergenic consensus (ERIC) sequence-primed PCR genomic fingerprints. In other studies based on AP-PCR (Van Couwenberghe et al., 1995; Yao et al., 1995) and PFGE (Yao et al., 1995), only a few strains from the same intensive care unit showed identical genomic profiles, thus suggesting nosocomial transmission. The majority of the strains though had distinct unique genomic profiles.

The diversity of genomic patterns obtained by different molecular fingerprinting techniques suggest that a reservoir of $S$. maltophilia strains exists in the environment, from which certain strains adopt as opportunists. These strains are usually multidrug resistant (Spencer, 1995; Zuravleff \& Yu, 1982). The question thus arose as to what degree of relationship there exists between strains isolated from nosocomial infections on the one hand and strains isolated from diverse ecological niches on the other hand.

In the present study we have investigated more than 100 presumptive $S$. maltophilia strains collected from various environmental and clinical sources by means of the sensitive genomic AFLP fingerprinting method. The authors who invented the method recommend not to use the name AFLP as an acronym (Vos et al., 1995). The AFLP technique has been previously used with success for taxonomy and fine-typing of bacteria (Huys et al., 1996; Janssen et al., 1996). This method was chosen here because it offers patterns with a large number of distinct bands representing the entire genome, thus being suitable for the detection both of broad (phylogenetic) and narrow (clonal) relationships. A selected set of strains was further analysed by means of DNA hybridization and 16S rDNA sequencing in order to assess the genomic homogeneity and the 16S rRNA gene variability of the species S. maltophilia.

\section{METHODS}

Bacterial strains. All of the strains used in this study are listed in Table 1. They were obtained from the culture collection of the Laboratorium voor Microbiologie, Universiteit Gent, Ghent, Belgium, or were kindly provided by J. Debette (University of Sciences and Techniques, Lille, France), W. Hansen (University Hospital Brugmann, Brussels, Belgium), H. Goossens (University Hospital St Pieter, Brussels, Belgium) and P. Goullet (Beaujon Hospital, Paris, France). Strains were cultured for $48 \mathrm{~h}$ on solid medium containing $3 \%$ Trypticase soy broth (BBL) and $2 \%$ technical agar. All strains were received as $X$. maltophilia or $P$. maltophilia, which was confirmed using API 20 NE test strips and Biolog GN microtitre plates. Fatty acid analyses by the MIS system of all strains matched the $S$. maltophilia profile as described by Yang et al. (1993b).

Isolation and purification of DNA for AFLP fingerprinting. Approximately $10 \mu \mathrm{g}$ wet cells was suspended in $1 \mathrm{ml}$ resuspension buffer (150 mM NaCl, 10 mM EDTA; pH 8.0) and centrifuged for $10 \mathrm{~min}$ at $15000 \mathrm{~g}$. The pelleted cells were resuspended in $100 \mu \mathrm{l}$ TE buffer $(10 \mathrm{mM}$ Tris $/ \mathrm{HCl}$, $1 \mathrm{mM}$ EDTA; pH 7.6) and lysed with $500 \mu \mathrm{l}$ GES reagent [5 mM guanidium thiocyanate, $100 \mathrm{mM}$ EDTA, $0.5 \%(\mathrm{v} / \mathrm{v})$ $N$-lauroyl sarcosine]. The DNA was extracted with chloroform/isoamyl alcohol $(24: 1, \mathrm{v} / \mathrm{v})$, precipitated with $0.54 \mathrm{vol}$. 2-propanol, washed twice with $150 \mu 170 \%(\mathrm{v} / \mathrm{v})$ ethanol, and dried in sterile air flow for $10 \mathrm{~min}$. DNA pellets were redissolved in $200 \mu \mathrm{T}$ TE buffer and incubated for $1 \mathrm{~h}$ with $50 \mu \mathrm{l}$ DNase-free RNase $\left(250 \mu \mathrm{g} \mathrm{ml}^{-1}\right)$. The DNA concentrations were measured spectrophotometrically at $260 \mathrm{~nm}$ and the high molecular masses of the DNA preparations were verified by electrophoresing $10 \mu 1$ of the DNA samples in $1 \%$ agarose gels containing $0.5 \mu \mathrm{g}$ ethidium bromide $\mathrm{ml}^{-1}$.

Preparation of template DNA for PCR. An amount of $1 \mu \mathrm{g}$ DNA was digested with ApaI and TaqI (Pharmacia Biotech) and subsequently ligated with T4 ligase (Pharmacia Biotech) to equimolar amounts of oligonucleotide sequence complements 5'-TCGTAGACTGCGTACAGGCC-3' and 5'-TGTACGCAGTCTAC-3' complementary to the $\mathrm{ApaI}$ restriction halfsite and 5'-GACGATGAGTCCTGAC-3' and 5'CGGTCAGGACTCCAT-3' complementary to the TaqI restriction halfsite. Thus obtained templates were precipitated with $1.25 \mathrm{M}$ ammonium acetate and $50 \%(\mathrm{v} / \mathrm{v}) 2$ propanol, washed with $70 \%(\mathrm{v} / \mathrm{v})$ ethanol and resuspended in $100 \mu \mathrm{l}$ buffer containing $10 \mathrm{mM}$ Tris, $0 \cdot 1 \mathrm{mM}$ EDTA (pH 8.0).

Primer labelling and selective PCR amplification. The following selective PCR primers were used: 5'-GACTGCGTACAGGCCCG-3', complementary to the ApaI restriction site and adaptor, with a 3 -terminal guanine as single selective extension base, and 5'-CGATGAGTCCTGACCGAG- $3^{\prime}$, complementary to the TaqI restriction site and adaptor, also with a $3^{\prime}$-terminal guanine as single selective extension base. The TaqI primer was radioactively labelled with $\left[\gamma^{32}\right.$ P]ATP (Amersham International) using bacteriophage T4 polynucleotide kinase (Pharmacia Biotech).

Electrophoresis and visualization of banding patterns. Amplified fragments were electrophoresed on $5 \%$ denaturing polyacrylamide gels containing $4.75 \%(\mathrm{w} / \mathrm{v})$ acrylamide, $0.25 \%(\mathrm{w} / \mathrm{v})$ methylene bisacrylamide, $8.3 \mathrm{M}$ urea, $100 \mathrm{mM}$ Tris, $100 \mathrm{mM}$ boric acid, $2 \mathrm{mM}$ EDTA; pH 8.3. The gels were vacuum-dried with a gel dryer (model 58 ; Bio-Rad) for $55 \mathrm{~min}$ at $80^{\circ} \mathrm{C}$. The AFLP fingerprints were visualized autoradiographically by exposing the dried gels to Hyper- 
Table 1. S. maltophilia strains investigated together with their origin and accession numbers of their 165 rRNA gene sequences in the EMBL database

Culture collections: ATCC, American Type Culture Collection, Manassas, VA, USA; CCM, Czechoslovak Collection of Microorganisms, Brno, Czechoslovakia; CIP, Collection Bactérienne de l'Institut Pasteur, Paris, France; DSM, Deutsche Sammlung von Microorganismen und Zellkulturen, Braunschweig, Germany; IFO, Institute for Fermentation, Osaka, Japan; JCM, Japan Collection of Microorganisms, Institute of Physical and Chemical Research, Saitama, Japan; LMG, Laboratorium voor Microbiologie Gent Culture Collection, Universiteit Gent Belgium; NCIB, National Collection of Industrial Bacteria, NCIMB, Aberdeen, UK; NCMB, National Collection of Marine Bacteria, NCIMB, Aberdeen, UK; NCPPB, National Collection of Plant Pathogenic Bacteria, Harpenden Laboratory, Hertfordshire, UK.

\begin{tabular}{|c|c|c|c|c|c|}
\hline & LMG no. & Other strain no. & Source & $\begin{array}{c}\text { Genomic } \\
\text { group }\end{array}$ & $\begin{array}{c}\text { EMBL } \\
\text { no. }\end{array}$ \\
\hline 1 & $957 \mathrm{t} 1$ & ATCC 17448 & Human blood culture & NG & AJ 131114 \\
\hline 2 & $957 \mathrm{t} 2$ & ATCC 17448 & Human blood culture & NG & \\
\hline 3 & $958^{\mathrm{T}}$ & ATCC 13637 & Cortical necrosis, patient with oral cancer & 6 & X95923 \\
\hline 4 & 959 & ATCC 17806 & Rice paddies, Japan & 9 & \\
\hline 5 & 960 & CIP 59.60 & Contaminated tissue culture & 5 & \\
\hline 6 & $961 \mathrm{tl}$ & ATCC 13636 & Spinal fluid & 6 & \\
\hline 7 & $961 t 2$ & ATCC 13636 & Spinal fluid & 6 & \\
\hline 8 & 978 & NCPPB 323 & Piper beetle & NG & AJ131919 \\
\hline 9 & 980 & NCPPB 1683 & Hibiscus rosa-sinensis & NG & AJ131913 \\
\hline 10 & 981 & CCM 284 & Soil & NG & $\mathrm{AJ} 131116$ \\
\hline 11 & 1098 & NCMB 200 & Skin from Raja batis (fish) & 5 & \\
\hline 12 & 1108 & NCMB 211 & Gills from Raja batis (fish) & 5 & \\
\hline 13 & 6606 & Leyns 4M11 B 27.1 & Rhizosphere & 9 & \\
\hline 14 & 6607 & Leyns 5A31 A 18.1 & Rhizosphere & 9 & \\
\hline 15 & 6608 & Leyns 6M11 D 1.16 & Rhizosphere & 9 & AJ131918 \\
\hline 16 & 7958 & Stevens D1 & & NG & \\
\hline 17 & 7959 & Stevens D2 & & 4 & \\
\hline 18 & 10841 & CIP 54.90 & Human blood & 1 & \\
\hline 19 & 10848 & DSM 50173 & Contaminant from streptomycin solution & 2 & \\
\hline 20 & 10849 & Goossens I & Hospital infection & 5 & \\
\hline 21 & 10850 & Goossens 1 & Human blood culture & 3 & \\
\hline 22 & 10851 & Goossens 19 & Human blood culture & 5 & AJ131780 \\
\hline 23 & 10852 & Goossens 26 & Human blood culture & 6 & \\
\hline 24 & 10853 & Goossens 28 & Sputum & 3 & AJ131914 \\
\hline 25 & 10854 & Goossens 29 & Human blood culture & 2 & \\
\hline 26 & 10855 & Goossens 30 & Human blood culture & 7 & \\
\hline 27 & 10856 & Goossens 33 & Human blood culture & 6 & \\
\hline 28 & 10857 & Goossens 34 & Human blood culture & 10 & AJ131117 \\
\hline 29 & 10858 & Goossens 35 & Human blood culture & 3 & \\
\hline 30 & 10859 & Goossens 59 & Sputum & 1 & \\
\hline 31 & 10860 & Goossens 62 & Human blood culture & 5 & \\
\hline 32 & 10871 & ATCC 13270 & Soil & 10 & $\mathrm{AJ} 131781$ \\
\hline 33 & 10872 & ATCC 13843 & Contaminated tissue culture & 3 & \\
\hline 34 & 10873 & ATCC 15099 & Case of conjunctivitis & 7 & AJ131782 \\
\hline 35 & 10874 & ATCC 17671 & Human blood culture & 4 & AJ131783 \\
\hline 36 & 10875 & ATCC 17672 & Sputum & 4 & \\
\hline 37 & 10876 & ATCC 17674 & Cerebrospinal fluid & 4 & \\
\hline 38 & 10877 & ATCC 17676 & Patient with sinusitis, pus & 5 & AJ 131784 \\
\hline 39 & 10878 & ATCC 17677 & Patient with otitis, pus & 4 & \\
\hline 40 & 10879 & ATCC 17807 & Rice paddy & 9 & AJ131903 \\
\hline 41 & 10880 & ATCC 29510 & Female human & 7 & \\
\hline 42 & 10881 & JCM 1978 & Fish & NG & AJ131904 \\
\hline 43 & 10882 & JCM 1979 & Sewage & NG & AJ131905 \\
\hline 44 & 10883 & JCM 1981 & Frozen fruit & 1 & AJ131906 \\
\hline 45 & 10884 & JCM 1982 & Phenol enrichment culture & 4 & \\
\hline 46 & 10885 & JCM 1983 & Manured oil & 9 & \\
\hline 47 & $10886 \mathrm{t} 1$ & JCM 1985 & Manured oil & NG & \\
\hline
\end{tabular}


Table 1 (cont.)

\begin{tabular}{|c|c|c|c|c|c|}
\hline & LMG no. & Other strain no. & Source & $\begin{array}{c}\text { Genomic } \\
\text { group }\end{array}$ & $\begin{array}{c}\text { EMBL } \\
\text { no. }\end{array}$ \\
\hline 48 & $10886 \mathrm{t} 2$ & JCM 1985 & Manured oil & NG & \\
\hline 49 & 10887 & JCM 3800 & Oil brine & NG & \\
\hline 50 & 10888 & JCM 3801 & Oil brine & NG & AJ131915 \\
\hline 51 & 10889 & IFO 13692 & & & \\
\hline 52 & 10890 & IFO 13923 & Soil & 9 & \\
\hline 53 & 10954 & NCIB 9202 & Oropharyngeal swab from normal adult & 6 & \\
\hline 54 & 10955 & NCIB 9204 & Stagnant water & 4 & \\
\hline 55 & 10956 & NCIB 11534 & Soil & 3 & \\
\hline 56 & 10989 & Hansen 0230 & Gall & NG & AJ131907 \\
\hline 57 & 10990 & Hansen 0294 & Urine & 6 & \\
\hline 58 & 10991 & Hansen 0325 & Leg, pus & 2 & AJ131115 \\
\hline 59 & 10992 & Hansen 0362 & Expectoration & 6 & AJ131908 \\
\hline 60 & 10993 & Hansen 0408 & Pericardial drain & NG & \\
\hline 61 & 10994 & Hansen 0422 & Tracheal aspiration & 6 & \\
\hline 62 & 10995 & Hansen 0810 & Femoral top & 10 & \\
\hline 63 & 10996 & Hansen 1132 & Leg, ulcer & 2 & \\
\hline 64 & 10997 & Hansen 1151 & Rinsing water from gastrointestinal endoscope & 2 & \\
\hline 65 & 10998 & Hansen 1213 & Eye & 2 & \\
\hline 66 & 10999 & Hansen 2011 & Drinking water & 6 & \\
\hline 67 & 11000 & Hansen 2336 & Gall & 2 & \\
\hline 68 & 11001 & Hansen 2669 & Water bed & 3 & \\
\hline 69 & 11002 & Hansen 2749 & Mamilla & 3 & AJ131916 \\
\hline 70 & 11003 & Hansen 3286 & Tracheal aspiration & 7 & AJ131909 \\
\hline 71 & 11004 & Hansen 3340 & Urine & 2 & \\
\hline 72 & 11087 & $\mathrm{C} 17$ & Rhizosphere & 9 & X95924 \\
\hline 73 & 11088 & $\mathrm{C} 28$ & Rhizosphere & 9 & \\
\hline 74 & 11089 & Pl-1 & Cichorium intybus, rhizosphere tuberous roots & 5 & AJ 131910 \\
\hline 75 & $11090 \mathrm{t} 1$ & $\mathrm{P} 1-24$ & Cichorium intybus, rhizosphere tuberous roots & 5 & \\
\hline 76 & $11090 \mathrm{t} 2$ & $\mathrm{P} 1-24$ & Cichorium intybus, rhizosphere tuberous roots & 5 & \\
\hline 77 & 11091 & $\mathrm{P} 1-25$ & Cichorium intybus, rhizosphere tuberous roots & 5 & \\
\hline 78 & 11092 & $\mathrm{P} 1-34$ & Cichorium intybus, rhizosphere tuberous roots & 9 & \\
\hline 79 & 11093 & $\mathrm{P} 1-37$ & Cichorium intybus, rhizosphere tuberous roots & 5 & \\
\hline 80 & $11094 \mathrm{t} 1$ & $\mathrm{P} 1-41$ & Cichorium intybus, rhizosphere tuberous roots & 5 & \\
\hline 81 & $11094 \mathrm{t} 2$ & $\mathrm{P} 1-41$ & Cichorium intybus, rhizosphere tuberous roots & 5 & \\
\hline 82 & $11094 \mathrm{t} 3$ & P1-41 & Cichorium intybus, rhizosphere tuberous roots & 5 & \\
\hline 83 & 11095 & P1-44 & Cichorium intybus, rhizosphere tuberous roots & 5 & \\
\hline 84 & 11096 & $\mathrm{P} 1-47$ & Cichorium intybus, rhizosphere tuberous roots & 5 & \\
\hline 85 & 11097 & $\mathrm{P} 2-2$ & Cichorium intybus, rhizosphere tuberous roots & 9 & \\
\hline 86 & 11098 & S-3 & Cichorium intybus, rhizosphere tuberous roots & 9 & \\
\hline 87 & 11099 & S-50 & Cichorium intybus, rhizosphere tuberous roots & 9 & \\
\hline 88 & 11100 & S-51 & Cichorium intybus, rhizosphere tuberous roots & 9 & \\
\hline 89 & 11101 & S-53 & Cichorium intybus, rhizosphere tuberous roots & 9 & \\
\hline 90 & 11102 & S-61 & Cichorium intybus, rhizosphere tuberous roots & 9 & \\
\hline 91 & 11103 & E-18 & Cichorium intybus, rhizosphere tuberous roots & NG & AJ131911 \\
\hline 92 & $11104 \mathrm{t} 2$ & E-41 & Cichorium intybus, rhizosphere tuberous roots & NG & AJ131912 \\
\hline 94 & 11105 & B-5 & Triticum, rhizosphere & 8 & \\
\hline 95 & $11106 \mathrm{t} 1$ & B-15 & Triticum, rhizosphere & 8 & \\
\hline 96 & $11106 \mathrm{t} 2$ & B-15 & Triticum, rhizosphere & 8 & \\
\hline 97 & 11107 & B-30 & Triticum, rhizosphere & 8 & \\
\hline 98 & 11108 & RB-42 & Triticum, root & 8 & AJ131917 \\
\hline 99 & 11109 & RB-52 & Triticum, root & 8 & \\
\hline 100 & $11110 \mathrm{t} 1$ & RB-76 & Triticum, root & NG & \\
\hline 101 & $11110 \mathrm{t} 2$ & RB-76 & Triticum, root & NG & \\
\hline 102 & $11111 \mathrm{t} 1$ & 9005164 & Catheter & 2 & \\
\hline 103 & $11111 \mathrm{t} 2$ & 9005164 & Catheter & 2 & \\
\hline
\end{tabular}


Table 1 (cont.)

\begin{tabular}{|llllcc|}
\hline & LMG no. & Other strain no. & \multicolumn{1}{c}{ Source } & $\begin{array}{c}\text { Genomic } \\
\text { group }\end{array}$ & $\begin{array}{c}\text { EMBL } \\
\text { no. }\end{array}$ \\
\hline 104 & 11112 & 9001136 & Lung, puncture & 4 & \\
105 & 11113 & 890633 & Catheter & 6 & \\
106 & 11114 & 890188 & Human blood culture & 1 & $X 95925$ \\
107 & 11115 & 8808116 & Bronchae & 6 & 6 \\
108 & 11116 t 1 & 8810105 & Human blood culture & 6 \\
\hline
\end{tabular}

NG, Does not belong to a defined group.

film-MP (Amersham International) for 5-24 h depending on the amount of radiation determined with a regular GeigerMüller counter. Following exposure, the film was developed with a model RGII X-ray film processor (Fuji).

Densitometric scanning and data processing. Autoradiograms were scanned by using a high-resolution densitoscanner (model RayVen RSU1; X-Ray Scanner Corp.). Transmission image data were stored as TIFF files and were further processed by using the GELCOMPAR software, version 4.1 (Applied Maths)

DNA hybridization. DNAs were extracted and purified as described by Marmur (1961). The levels of DNA binding were determined from the initial renaturation rates by using a spectrophotometer (De Ley et al., 1970). The renaturation rates were determined in $2 \times \mathrm{SSC}$ at the optimal renaturation temperature, $80.8^{\circ} \mathrm{C}$, which was calculated from the $\mathrm{G}+\mathrm{C}$ contents as described by De Ley (1970) $(1 \times$ SSC is $0 \cdot 15 \mathrm{M}$ $\mathrm{NaCl}$ plus $0 \cdot 015$ sodium citrate).

16S rDNA sequencing. DNA preparation, PCR amplification and sequencing of $16 \mathrm{~S}$ rRNA genes were done as described previously (Hauben et al., 1997).

165 rDNA sequence comparison and phylogenetic analysis. Alignment, calculation of similarity values and cluster analysis were performed by using the GENECOMPAR software package (Applied Maths) after discarding all unknown base positions and gaps. The 16S rDNA sequences of Xanthomonas campestris LMG 568 (accession no. X95917), Xanthomonas albilineans LMG 494 (accession no. X95918), Xanthomonas sacchari LMG 471 (accession no. Y10766) and Xylella fastidiosa (accession no. M26601) were obtained from EMBL.

\section{RESULTS AND DISCUSSION}

The collection of $S$. maltophilia strains we used originated from a wide variety of environments and geographical regions.

Phenotypic typing methods have been applied earlier in an attempt to elucidate the epidemiology of $S$. maltophilia but were often poorly discriminative because of a scarcity of interstrain variability manifested by the bacterium (Schable et al., 1992; Van Nuffel, 1991; Yang et al., 1993a, b). Recently, genotypic typing techniques have received growing attention. Methods evaluated to study the epidemiology of $S$. maltophilia include ribotyping, PFGE, random amplification of polymorphic DNA (RAPD) and ERICPCR (Denton \& Kerr, 1998). By applying three genomic techniques with different resolving power for determining taxonomic hierarchies onto a wide collection of strains, the present study revealed a new view on the genomic diversity of the genus Stenotrophomonas.

\section{AFLP genomic fingerprinting}

The level of reproducibility was determined by using the AFLP pattern of strain LMG 10882 as reference during each electrophoresis run. Following normalization and subtraction of background, we found that the intragel-correlation levels for the reference samples varied from 92 to $97 \%$. Minimal differences in the correlation values between reference lanes were usually introduced by inevitable variations in background intensities and electrophoresis times. Fig. 1 shows normalized AFLP patterns for all strains, sorted according to a UPGMA dendrogram based upon the product-moment correlation between entire densitometric profiles. The combination of ApaI and TaqI as restriction enzymes and guanine as a single extension base for amplification revealed complex AFLP patterns composed of some 45-60 clearly distinguishable bands on average, with sizes between 50 and $600 \mathrm{bp}$ (Janssen et al., 1996). Strains LMG 11116, LMG 957 and LMG 11103 showed significantly less bands, a phenomenon which was reproducible in repeated experiments. Concurrent amplification of large numbers of fragments typically yielded bands with unequal intensities within a single pattern. This fact together with the large numbers of bands made it particularly difficult to assign discrete band positions to the patterns. Therefore, in order to avoid subjective interpretations of band positions, the Pearson product-moment correlation coefficient was applied to measure similarity between normalized densitometric profiles. This coefficient compares curves as a whole and is independent of band definitions. It is largely insensitive to relative concentrations, but sensitive to differences in background and it does not suffer from typical peak/shoulder mismatches (Vauterin \& Vauterin, 1992).

The $S$. maltophilia strains showed a remarkable heterogeneity in their AFLP profiles, reflected in the extremely low mean correlation values between the clusters, which range between 15 and $30 \%$. We defined 


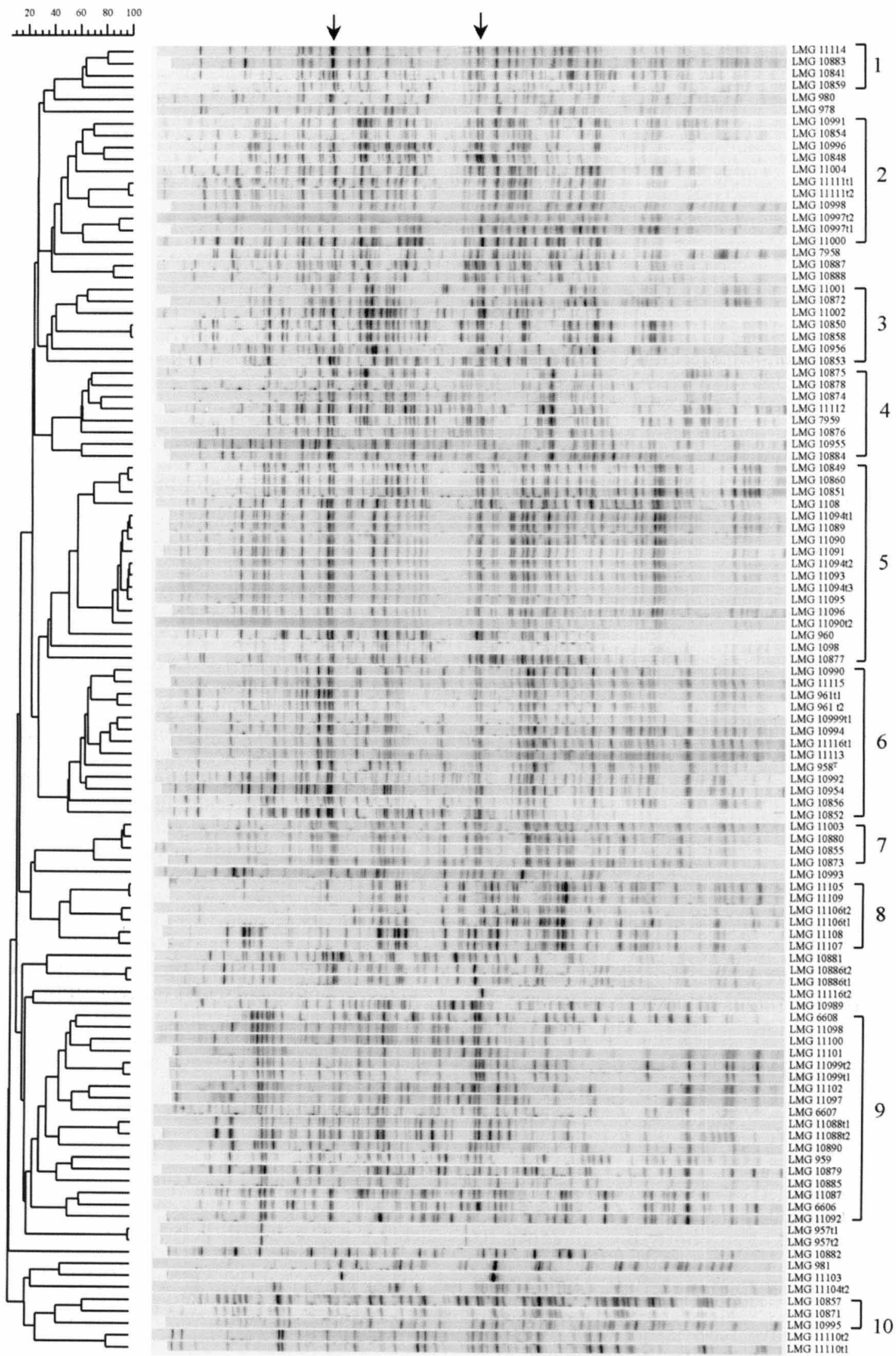

Fig. 1. For legend see facing page. 
ten more or less consistent clusters of highly similar genomes on the dendrogram, showing an internal mean correlation of $40 \%$ or higher, and characterized by a number of common bands between the profiles. These clusters are numbered from 1 to 10 on Fig. 1. The genomic heterogeneity revealed by AFLP fingerprinting within $S$. maltophilia was high in comparison with other bacterial groups that have been analysed by this technique. Within the genus Xanthomonas, the mean linkage level between species lay between 50 and $60 \%$ and within the genus Aeromonas, the mean linkage level between hybridization groups lay between 50 and $70 \%$ (Huys et al., 1996; Janssen et al., 1996). Two positioned bands or doublets in the AFLP profiles, indicated by an arrow (Fig. 1), were present for most of the $S$. maltophilia strains examined. These bands marked a minimal genomic resemblance within $S$. maltophilia, in spite of the complexity of the genomic fingerprints of the species.

Clusters 1 and 2 consist of clinical isolates only and showed an internal correlation of 61 and $39 \%$, respectively. Strains LMG 980 and LMG 978, two environmental isolates, grouped outside cluster 1 . Clusters 2 and 4 consisted of environmental isolates only and showed internal correlations of 45 and $38 \%$, respectively. Strain LMG 7958 and two isolates from oil brine, LMG 10887 and LMG 10888, clustered outside AFLP group 2. The banding patterns of the latter two strains were very similar with a correlation level of $85 \cdot 2 \%$. Clusters 3 and 6 contain clinical as well as environmental isolates and correlated internally at 34 and $51 \%$, respectively. The type strain of Stenotrophomonas maltophilia, LMG $958^{\mathrm{T}}$, grouped in cluster 6. Cluster 7 consisted of four clinical isolates and had a high correlation level of $71 \%$. The banding pattern of strain LMG 10993, grouping outside this cluster, was clearly aberrant from the profiles of AFLP group 7. Clusters 8 and 9 consisted of environmental isolates only and correlated at the levels 45 and $25 \%$, respectively. The six strains of group 8 were divided into three pairs, each with very similar banding patterns. Strains LMG 979, LMG 10881, LMG 10886t2, LMG 10886t1, LMG 11116 t2 and LMG 10989 did not cluster within any of the AFLP groups and showed very divergent genomic profiles. The banding patterns of LMG $957 \mathrm{t1}$ and LMG $957 \mathrm{t} 2$ were identical but showed very few bands. Strains LMG 10882, LMG 981, LMG 11103 and LMG 11104t2 again showed high genomic variations. The last cluster, AFLP group 10 , contained two clinical isolates and one environmental one, correlating at a level of $43 \cdot 1 \%$.

More than one colony type existed within 12 LMG strains. For ten strains, the AFLP patterns of the different types were practically identical with correlation levels of $85 \%$ or more. The slight divergences in the banding profiles were due to fluctuating band intensities and not to different band positions. The different colony types distinguished within LMG 11111, LMG 10997, LMG 11094, LMG 11090, LMG 961, LMG 11106, LMG 10886, LMG 11099, LMG 11088 and LMG 957 could thus be considered as identical. For strain LMG 11110 , colony type 2 showed less bands than colony type 1 ; their correlation level was $82 \cdot 2 \%$. Colony type 1 and 2 of LMG 11116 were clearly completely different as they correlated at the level of $12.3 \%$ and the AFLP profile of type 2 contained only two bands. AFLP seems to be particularly suitable to examine the identity of colony types distinguished within certain strains.

\section{DNA hybridization}

A total of 168 DNA hybridization values were determined for 32 strains. All of the values presented below (Table 2) were the means of the values from at least two independent measurements.

At least two strains of AFLP groups 1, 2, 3, 4, 5, 6 and 9 were included in the DNA similarity study. The division of the $S$. maltophilia strains into AFLP groups was being reflected in the DNA hybridization data. AFLP groups 1, 2, 3, 4, 5, 6 and 9 exhibited genomic similarities of at least $58 \%$. A value of $58 \%$ occurred between strains LMG 10853 and LMG 11002 of group 3 and between strains LMG 10877 and LMG 10851 of group 5. Between strains LMG 10996 and LMG 11004 of group 2 and strains LMG 6608 and LMG 10890 of group 9, the lowest DNA similarity value observed was $65 \%$. Within AFLP groups 1,4 and 6 , the DNA similarity values were at least $75 \%$.

These values insinuated the possibility of considering AFLP groups 1, 4 and 6 as separate species as a DNA homology value of $70 \%$ is the generally accepted minimum value for strains within a species (Wayne $e t$ al., 1987). But analysing the DNA hybridization values in more detail proved that the separation of the groups was not very pronounced. The majority of the hybridization values $(82 \%)$ lay between 10 and $60 \%$ with a maximum ( $29 \%$ of the values) between 50 and $60 \%$; the values between the groups were not significantly lower that the values within the groups.

\section{5 rRNA gene sequencing}

Direct sequencing of the PCR-amplified 16S rDNA allowed us to determine a continuous stretch of 1298-1502 bases, ranging from positions 28 to 1524 of the 16S rRNA gene sequence of Escherichia coli. These

\footnotetext{
Fig. 1. Dendrogram derived from an unweighted average pair group cluster analysis of the AFLP patterns of all 108 S. maltophilia strains included in this study. Levels of linkage are expressed as the Pearson product-moment similarity coefficients.
} 


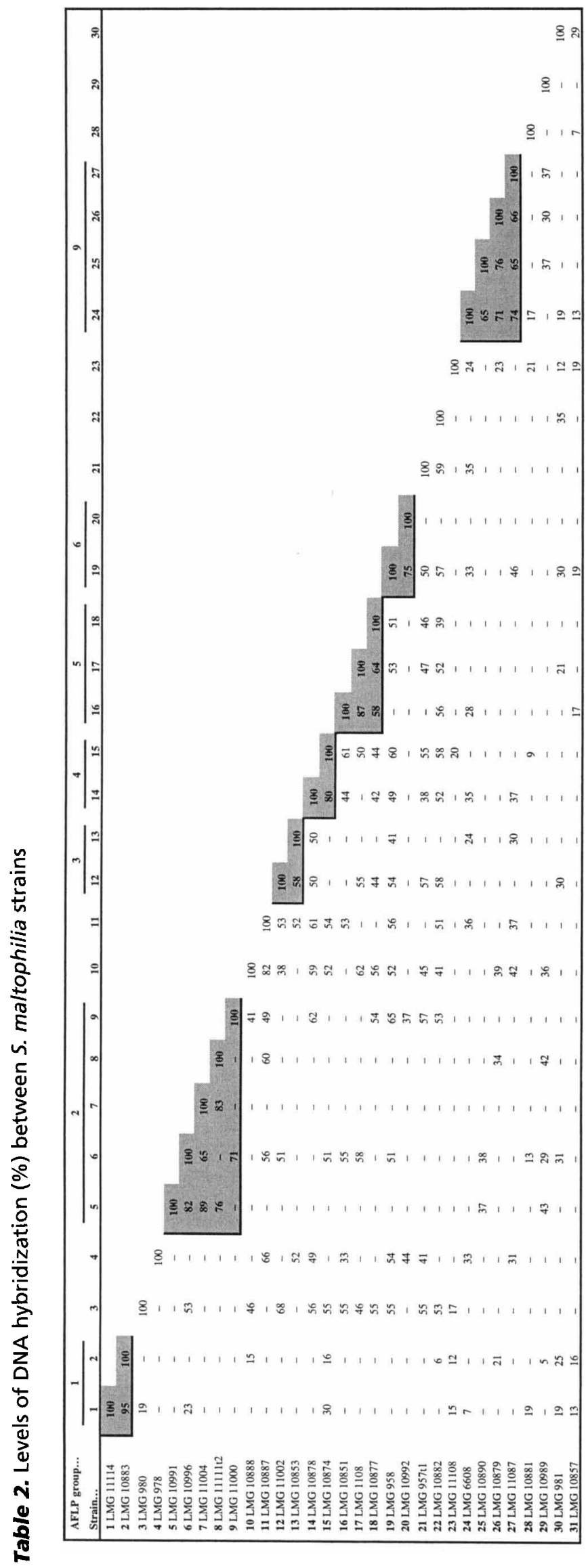




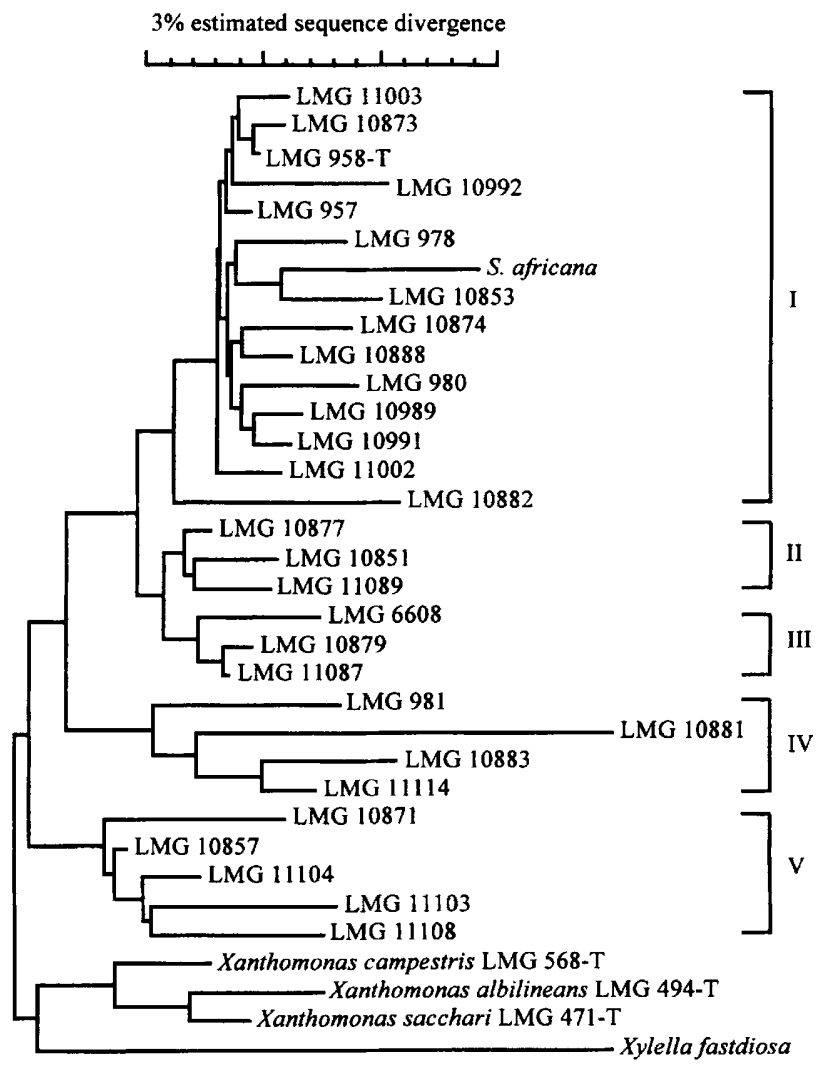

Fig. 2. Neighbour-joining dendrogram depicting estimated phylogenetic relationships based on pairwise comparisons of 165 rDNA sequences of 29 Stenotrophomonas strains, with $X$. campestris LMG $568^{\top}$ as an outgroup. The distance between two strains is obtained by adding the lengths of the connecting horizontal branches, using the scale at the top.

sequences corresponded to an estimated $85 \cdot 2-98 \cdot 6 \%$ of the total $16 \mathrm{~S}$ rDNA primary sequence. The sequence data were confirmed by sequencing the $16 \mathrm{~S}$ rDNA PCR products, for the most part, in both the forward and reverse directions.

A dendrogram depicting the estimated phylogenetic relationships (Fig. 2) was constructed by the neighbour-joining clustering method (Saitou \& Nei, 1987). This dendrogram was based on pairwise comparisons of 30 available $16 \mathrm{~S}$ rDNA sequences for the genus Stenotrophomonas.

Within the genus Stenotrophomonas, the mean 16S rDNA sequence similarity was $96.5 \%$, ranging from 91.6 to $99.7 \%$. Five sequence groups were defined (Fig. 2): sequence group I contained strains of AFLP groups 2, 3, 4, 6 and 7 and had a mean 16S rDNA sequence similarity of $98.1 \%$; sequence group II contained strains of AFLP group 5 and showed $98.8 \% 16 \mathrm{~S}$ rDNA sequence similarity on the mean; sequence group III contained strains of AFLP group 9 and sequence group IV contained strains of AFLP group 1 with a mean 16S rDNA sequence similarity of $99 \cdot 0$ and $98.4 \%$, respectively. Finally, sequence group V contained strains of AFLP groups 8 and 10 and showed
$97.7 \% 16 \mathrm{~S}$ rDNA sequence similarity on the mean. Of the ten AFLP groups, only groups 1, 5 and 9 could be distinguished as single groups by $16 \mathrm{~S}$ rDNA sequencing. The same five groups we defined by $16 \mathrm{~S}$ rDNA sequence comparisons were found after restriction endonuclease of the 16S rRNA gene of ten Stenotrophomonas strains (Nesme et al., 1995). The 16S rDNA sequence diversity within Stenotrophomonas was more pronounced than in the related genus Xanthomonas, where the mean sequence similarity value was $98.2 \%$. 16S rDNA sequence comparisons between the 20 Xanthomonas species resulted in three clusters: one around the type species $X$. campestris, one containing only $X$. sacchar $i$ and one around $X$. albilineans (Hauben et al., 1997). One 16S rDNA sequence of each of these clusters was included in Fig. 2.

Sequence group I contained the type strains of the two current species of Stenotrophomonas: S. maltophilia LMG $958^{\mathrm{T}}$ and $S$. africana CIP $10-48-54^{\mathrm{T}}$. They showed a $16 \mathrm{~S}$ rDNA sequence similarity of $97.2 \%$, which was higher than the mean 16S rDNA sequence similarity value within $S$. maltophilia. The species $S$. africana, recently found by Drancourt et al. (1997), was mainly based on a DNA homology level of $35 \%$ with the type strain of $S$. maltophilia. We believe that this value, determined by the S1 nuclease (TCA) method, is not a convincing argument to create a new species for one strain, especially since it is known that different techniques for determining levels of DNA relatedness yield different values. Between strains that are not highly related, the S1 nuclease method is known to produce rather low binding values compared to the nitrocellulose filter method and the spectrophotometric method (Grimont, 1988). In addition, there was only one feature (accumulation of cisaconitate) that discriminated the strain from other $S$. maltophilia strains, of which only the type strain was compared. Moreover, this feature was not known for other S. maltophilia strains. The results of this study have now revealed that low DNA hybridization values occur frequently in $S$. maltophilia and this might open some interesting perspectives for taxonomic splitters who can see various new Stenotrophomonas species arise. But what would the practical use be of this if there is momentarily no method available to differentiate them at the phenotypic level? A modern polyphasic species definition should be an intermediate one between the species definition by Wayne et al. (1987) and a new species definition which will be linked to extensive genotypic and phenotypic databases of strains.

As pointed out by Stackebrandt \& Goebel (1994), species possessing $70 \%$ or greater DNA similarity usually exhibit more than $97 \% 16 \mathrm{~S}$ rDNA sequence similarity. Our sequence data showed that for the genus Stenotrophomonas the value was even higher as all of the strains (four in total) that exhibited $70 \%$ or more DNA homology exhibited at least $98 \%$ sequence similarity. The correspondence between the DNA 


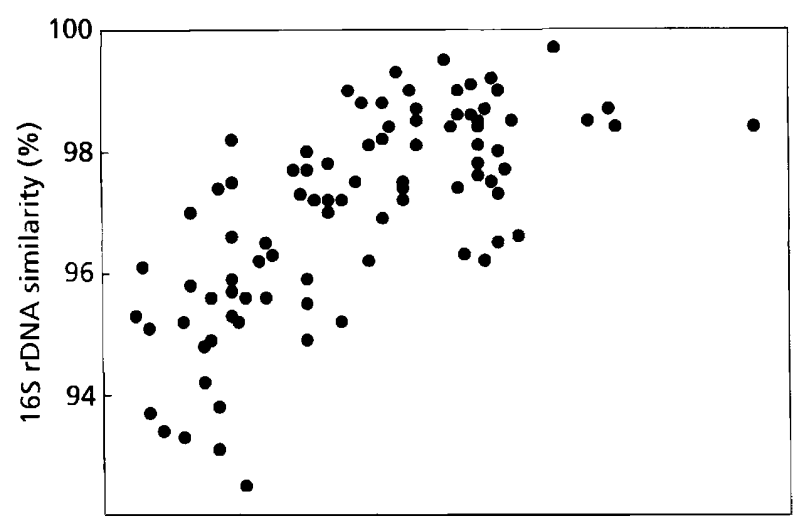

Fig. 3. Correlation plot of the DNA homology data versus levels of $16 \mathrm{~S}$ rDNA sequence similarity for $S$. maltophilia strains.

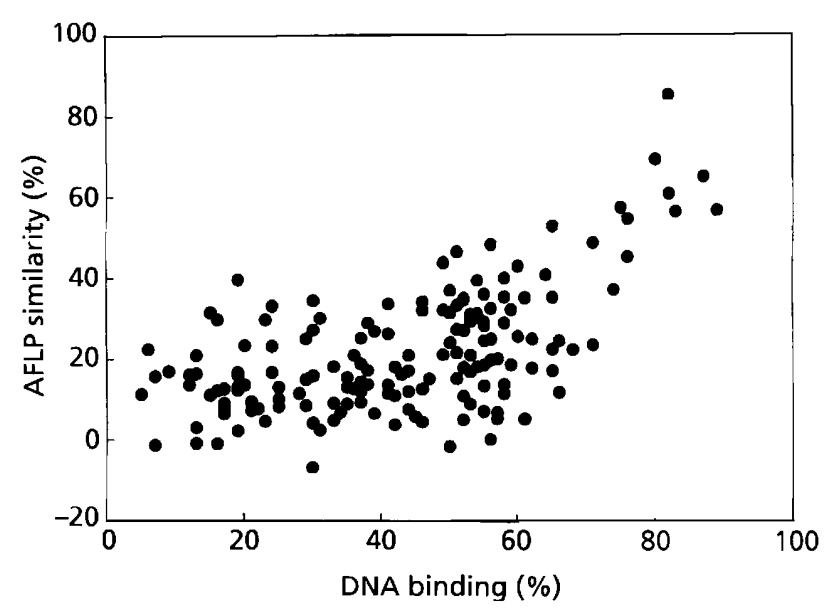

Fig. 4. Correlation plot of the DNA homology data versus correlation values between densitometric AFLP profiles of $S$. maltophilia strains.

similarity data determined by DNA-DNA hybridization and the $16 \mathrm{~S}$ rDNA sequence similarity data for the genus Stenotrophomonas has been evaluated, and the results are shown in Fig. 3. The percentages of sequence similarity for all of the sequenced Stenotrophomonas strains are plotted against the DNA-DNA similarity values in Fig. 3. Within the genus Stenotrophomonas, there was a correlation between the two sets of data; organisms that exhibited levels of DNA similarity higher than $40 \%$, always exhibited levels of $16 \mathrm{~S}$ rDNA similarity higher than $96 \%$. This area contained the correlation data derived from pairwise comparisons of the strains within and between sequence groups I, II and III, and within sequence group IV. Levels of DNA similarity less than $40 \%$ corresponded to $16 \mathrm{~S}$ rDNA sequence similarities between 92 and $99 \%$. The correlation between 16S rDNA similarities and DNA similarities in Stenotrophomonas was more pronounced than for the related genus Xanthomonas (Hauben et al., 1997), which could be attributed to the difference in genomic heterogeneity between these two genera.

The correspondence between the DNA similarity data determined by DNA-DNA hybridization and the AFLP fingerprinting data for the genus Stenotrophomonas has been evaluated as well, and the results are shown in Fig. 4. Within the genus Stenotrophomonas, organisms exhibiting levels of DNA similarity higher than $75 \%$ always exhibited levels of AFLP similarity higher than $55 \%$. This area contained similarities measured by the Pearson product-moment correlation coefficient of the strains within AFLP groups 1, 2, 4, 5, 6 and 9. Levels of DNA similarities higher than $70 \%$ corresponded to AFLP similarities higher than $50 \%$. Levels of DNA similarity less than $70 \%$ corresponded to AFLP similarities between 0 and $50 \%$. The high overall level of correlation between AFLP fingerprinting and DNA hybridization data have indicated that the AFLP method can be considered a relatively fast, reproducible, high-resolution alternative to conventional DNA-DNA hybridization at the subgeneric level (Huys et al., 1996).

\section{Conclusions}

With continuing advances in medical technology and the growth of debilitated or immunocompromised populations, the incidence of infection associated with $S$. maltophilia will certainly increase. The data presented in this study are a major contribution to the understanding of the epidemiology of the species $S$. maltophilia. Despite the lack of significant phenotypic interstrain variability within S. maltophilia, we demonstrated that their genomes differ a lot. Ten genomic groups could be delineated by AFLP which are largely supported by DNA hybridization data and partly by $16 \mathrm{~S}$ rDNA sequence data. The relatively high intergroup DNA hybridization data and the lack of characteristic phenotypes for the genomic groups prevented us from describing them as novel species. The conformity of the three genomic techniques applied in this study proved though that the genus Stenotrophomonas contains several cores of genomically more related strains which we describe as genomic groups $1,2,3,4,5,6,7,8,9$ and 10 containing the strains as pointed out in Table 1 and Fig. 1.

\section{ACKNOWLEDGEMENTS}

L. V. and J.S. acknowledge the Algemeen Bestuur voor de Ontwikkelingssamenwerking. Part of this work was carried out in the framework of Human Capital and Mobility Network grant CHRX CT93-0194 and Concerted Action Exploration of Microbial Diversity grant B102-CT93-0119. We thank A. Krüger and G. Vanderkimpen for excellent technical assistance. 


\section{REFERENCES}

Aznar, R., Alcaide, E. \& Garay, E. (1992). Numerical taxonomy of pseudomonads isolated from water, sediment and eels. Syst Appl Microbiol 14, 235-246.

Blahova, J., Kralikova, K., Krcmery, V. \& Torsova, V. (1997). Transferable antibiotic resistance in nosocomial Stenotrophomonas maltophilia strain. Diagn Microbiol Infect Dis 29. 129-132.

Boonchan, S., Britz, M. L. \& Stanley, G. A. (1998). Surfactantenhanced biodegradation of high molecular weight polycyclic aromatic hydrocarbons by Stenotrophomonas maltophilia. Biotechnol Bioeng 59, 482-494.

Borowicz, J. J., Brishammer, S. \& Gerhardson, B. (1995). A Xanthomonas maltophilia isolate tolerating up to 1 percent sodium azide in Tris/ $\mathrm{HCl}$ buffer. World J Microbiol Biotechnol 11, 236-237.

Chatelut, M., Dournes, J. L., Chabanon, G. \& Marty, N. (1995). Epidemiological typing of Stenotrophomonas (Xanthomonas) maltophilia by PCR. J Clin Microbiol 33, 912-914.

Debette, J. \& Blondeau, R. (1977). Caractérization de bactéries telluriques assimilables à Pseudomonas maltophilia. Can $J$ Microbiol 23, 1123-1127.

Debette, J. \& Blondeau, R. (1980). Présence de Pseudomonas maltophilia dans la rhizosfère de quelques plantes cultivées. Can $J$ Microbiol 26, 460-463.

De Ley, J. (1970). Re-examination of the association between melting point, buoyant density, and chemical base composition of deoxyribonucleic acid. $J$ Bacteriol 101, 738-754.

De Ley, J., Cattoir, H. \& Reynaerts, A. (1970). The quantitative measurement of DNA hybridization from renaturation rates. Eur J Biochem 12, 133-142.

Denton, M. \& Kerr, K. G. (1998). Microbiological and clinical aspects of infection associated with Stenotrophomonas maltophilia. Clin Microbiol Rev 11, 57-80.

Drancourt, M., Bollet, C. \& Raoult, D. (1997). Stenotrophomonas africana sp. nov., an opportunistic human pathogen in Africa. Int $J$ Syst Bacteriol 47, 160-163.

Fages, J. \& Arsac, J. F. (1991). Sunflower inoculation with Azospirillum and other plant growth promoting rhizobacteria. Plant and Soil 137, 87-90.

Fisher, M. C., Long, S. S., Roberts, E. M., Dunn, J. M. \& Balsara, R. K. (1981). Pseudomonas maltophilia bacteraemia in children undergoing open heart surgery. $J$ Am Med Assoc 246, 1571-1574.

Grimont, P. A. D. (1988). Use of DNA reassociation in bacterial classification. Can J Microbiol 34, 541-546.

Hauben, L., Vauterin, L., Swings, J. \& Moore, E. R. B. (1997). Comparison of $16 \mathrm{~S}$ ribosomal DNA sequences of all Xanthomonas species. Int $J$ Syst Bacteriol 47, 328-335.

Heath, T. \& Currie, B. (1995). Nosocomial and communityacquired Xanthomonas maltophilia infection in tropical Australia. J Hosp Infect 30, 309-313.

Hugh, R. (1981). Pseudomonas maltophilia sp. nov. nom. rev. Int $J$ Syst Bacteriol 31, 195.

Huys, G., Coopman, R., Janssen, P. \& Kersters, K. (1996). Highresolution genotypic analysis of the genus Aeromonas by AFLP fingerprinting. Int J Syst Bacteriol 46, 572-580.

lizuka, H. \& Komagata, K. (1963). Taxonomy of the genus Pseudomonas with special reference to their modes of metabolism of carbon compounds. J Gen Appl Microbiol 9, 83-95. lizuka, H. \& Komagata, K. (1964). Microbiological studies on petroleum and natural gas. 1. Determination of hydrocarbonutilizing bacteria. J Gen Appl Microbiol 10, 207-221.

Janssen, P., Coopman, R., Huys, G., Swings, J., Bleeker, M., Vos, P., Zabeau, M. \& Kersters, K. (1996). Evaluation of the DNA fingerprinting method AFLP as a new tool in bacterial taxonomy. Microbiology 142, 1881-1893.

Juhnke, M. E., Mathre, D. E. \& Sands, D. C. (1987). Identification and characterization of rhizosphere-competent bacteria of wheat. Appl Environ Microbiol 53, 2793-2799.

Laing, F. P. Y., Ramotar, K., Read, R. R., Alfieri, N., Kureishi, A., Henderson, E. A. \& Louie, T. J. (1995). Molecular epidemiology of Xanthomonas maltophilia colonization and infection in the hospital environment. $J$ Clin Microbiol 33, 513-518.

Lambert, B., Leyns, F., Van Rooyen, L., Gosselé, F., Papon, Y. \& Swings, J. (1987). Rhizobacteria of maize and their antifungal activities. Appl Environ Microbiol 53, 1866-1871.

Lambert, B., Meire, P., Joos, H., Lens, P. \& Swings, J. (1990). Fastgrowing, aerobic, heterotrophic bacteria from the rhizosphere of young sugar beet plants. Appl Environ Microbiol 56, 3375-3381.

Leifert, C. \& Waites, W. M. (1992). Bacterial growth in plant tissue culture media. $J$ Appl Bacteriol 72, 460-466.

Lesco-Bornet, M. \& Bergogne-Berezin, E. (1997). Susceptibility of 100 strains of Stenotrophomonas maltophilia to three $\beta$-lactams and five $\beta$-lactam- $\beta$-lactamase inhibitor combinations. $J$ Antimicrob Chemother 40, 717-720.

Marmur, J. (1961). A procedure for the isolation of deoxyribonucleic acid from microorganisms. $J \mathrm{Mol}$ Biol 3, 208-218.

Mett, H., Rosta, S., Schacher, B. \& Frei, R. (1988). Outer membrane permeability and $\beta$-lactamase content in Pseudomonas maltophilia clinical isolates and laboratory mutants. Rev Infect Dis 14, 765-769.

Nagai, T. (1984). Association of Pseudomonas maltophilia with malignant lesions. J Clin Microbiol 20, 1003--1005.

Nesme, X., Vaneechoutte, M., Orso, S., Hoste, B. \& Swings, J. (1995). Diversity and genetic relatedness within genera Xanthomonas and Stenotrophomonas using restriction endonuclease site differences of PCR-amplified 16S rRNA gene. Syst Appl Microbiol 18, 127-135.

Norrby, S. R. (1995). Carbapenems. Med Clin N Am 79, 745-759. Palleroni, N. J. \& Bradbury, J. F. (1993). Stenotrophomonas, a new bacterial genus for Xanthomonas maltophilia (Hugh 1980) Swings et al. 1983. Int J Syst Bacteriol 43, 606-609.

Penland, R. L. \& Wilhelmus, K. R. (1996). Stenotrophomonas maltophilia ocular infections. Arch Ophthalmol 114, 433-436.

Roilides, E., Buttler, K. M., Husson, R. N., Mueller, B. U., Lewis, L. L. \& Pizzo, P. A. (1992). Pseudomonas infections in children with human immunodeficiency virus infection. Pediatr Infect Dis $J$ 11, 547-553.

Saitou, N. \& Nei, M. (1987). The neighbor joining method: a new method for reconstructing phylogenetic trees. Mol Biol Evol 4, 406-425

Sanders, C. C. \& Sanders, W. E., Jr (1992). $\beta$-Lactam resistance in gram-negative bacteria: global trends and clinical impact. Clin Infect Dis 15, 824-839.

Schable, B., Rhoden, D. L., Jarvis, W. R. \& Miller, J. M. (1992). Prevalence of serotypes of Xanthomonas maltophilia from worldwide sources. Epidemiol Infect 108, 337-341. 
Spencer, R. C. (1995). The emergence of epidemic, multipleantibiotic-resistant Stenotrophomonas (Xanthomonas) maltophilia and Burkholderia (Pseudomonas) cepacia. $J$ Hosp Infect 30, 453-464.

Stackebrandt, E. \& Goebel, B. M. (1994). Taxonomic note: a place for DNA-DNA reassociation and 16S rRNA sequence analysis in the present species definition in bacteriology. Int $J$ Syst Bacteriol 44, 846-849.

Suzuki, Y., Koguchi, M., Tanaka, S., Fukiyama, S., Ishihara, R., Deguchi, K., Oda, S., Nakane, Y. \& Fukumoto, T. (1995). Frequency of clinical isolation of glucose non-fermentative rods and their susceptibilities to antibacterial agents. Jpn J Antibiot 48, 1264-1273.

Swings, J., De Vos, P., Van den Mooter, M. \& De Ley, J. (1983). Transfer of Pseudomonas maltophilia Hugh 1981 to the genus Xanthomonas as Xanthomonas maltophilia (Hugh 1981) comb. nov. Int J Syst Bacteriol 33, 409-413.

Swings, J., Vauterin, L. \& Kersters, K. (1993). The bacterium Xanthomonas. In Xanthomonas, pp. 121-156. Edited by J. G. Swings \& E. L. Civerolo. London: Chapman \& Hall.

Van Couwenberghe, C. J., Cohen, S. H., Tang, Y. J., Gumerlock, P. H. \& Silva, J., Jr (1995). Genomic fingerprints of epidemic and endemic strains of Stenotrophomonas maltophilia (formerly Xanthomonas maltophilia) by arbitrarily primed PCR. J Clin Microbiol 33, 1289-1291.

Van Nuffel, K. (1991). Karakterisatie van Xanthomonas maltophilia door middel van gelelektroforese van eiwitten en het Biolog systeem. Licentiaatsthesis, University of Ghent.

Vartivarian, S. E., Papadakis, K. A. \& Anaissie, E. J. (1996). Stenotrophomonas (Xanthomonas) maltophilia urinary tract infection. A disease that is usually severe and complicated. Arch Intern Med 156, 433-435.
Vauterin, L. \& Vauterin, P. (1992). Computer-aided objective comparison of electrophoresis patterns for grouping and identification of microorganisms. Eur Microbiol 1, 37-41.

Vos, P., Hogers, R., Bleeker, M. \& 8 others (1995). AFLP: a new concept for DNA fingerprinting. Nucleic Acid Res 21, 4407-4414.

Wallace, W. H., Rice, J. F., White, D. C. \& Sayler, G. S. (1994). Distribution of alginate genes in bacterial isolates from corroded metal surfaces. Microb Ecol 27, 213-223.

Wayne, L. G., Brenner, D. J., Colwell, R. R. \& 9 other authors (1987). International Committee on Systematic Bacteriology. Report of the ad hoc committee on reconciliation of approaches to bacterial systematics. Int $J$ Syst Bacteriol 37, 463-464.

Wilkinson, K. G., Dixon, K. W., Sivasithamparam, K. \& Ghisalberti, E. L. (1994). Effect of IAA on symbiotic germination of an Australian orchid and its production by orchid-associated bacteria. Plant Soil 159, 291-295.

Yang, P., De Vos, P., Kersters, K. \& Swings, J. (1993a). Polyamine patterns as chemotaxonomic markers for the genus Xanthomonas. Int J Syst Bacteriol 43, 709-714.

Yang, P., Vauterin, L., Vancanneyt, M., Swings, J. \& Kersters, K. (1993b). Application of fatty acid methyl esters for the taxonomic analysis of the genus Xanthomonas. Syst Appl Microbiol 16, 47-71.

Yao, J. D. C., Conly, J. M. \& Krajden, M. (1995). Molecular typing of Stenotrophomonas maltophilia by DNA macrorestriction analysis and random amplified polymorphic DNA analysis. $J$ Clin Microbiol 33, 2195-2198.

Zuravleff, J. J. \& Yu, V. L. (1982). Infections caused by Pseudomonas maltophilia with emphasis on bacteraemia: reports and a review of the literature. Rev Infect Dis 4, 1242-1246. 